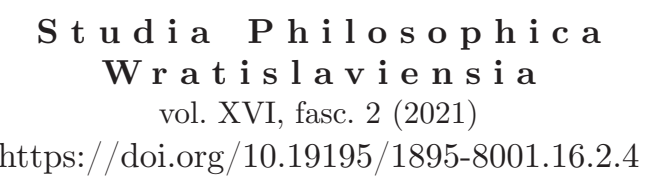

\author{
FUNDA GÜNSOY \\ ORCID: 0000-0001-8764-8368 \\ Bursa Uludag University
}

\title{
Philosophy, revelation and politics: The recovery of medieval Islamic political philosophy
}

\begin{abstract}
In contemporary philosophical thought, Leo Strauss is associated with the rediscovery of ancient political philosophy against modern political philosophy. The rediscovery of ancient political philosophy is the rediscovery of classical rationalism or "moderate Enlightenment" against modern rationalism or "radical Enlightenment" and can be understood as recapturing the "the question of man's right life" and "the question of the right order of society". This article would like to show that it was his study of medieval Islamic and Jewish texts that enabled Strauss to rediscover the classical rationalism. Also, in this article we would like to argue that although the opposition between Athens and Jerusalem, Reason and Revelation embodies two irreconcilable alternatives or a way of life in his thought, this opposition should be only examined with references to claims about radical rationalism of modern philosophy. In this case, we would like to argue that there can be seen a commonality between these "opponents", i.e., Athens and Jerusalem, Reason and Revelation in terms of both their attitudes towards morality and their approaches to the relationship between philosophy and society.
\end{abstract}

Keywords: Leo Strauss, Islamic Political Philosophy, al-Farabi, Maimonides, Reason, Revelation

The understanding of the Greek rationalism and biblical morality as the two conflicting "roots" of Western civilization is the most important and well-known part of Leo Strauss's philosophical thought. Indeed, we can say the he has revi- 
talised classical (as well as medieval) political philosophy and has restored the original meaning of philosophy as a genuine emancipatory activity. ${ }^{1}$ He dedicated his entire academic life to the non-traditional reading and study of the texts of ancient and modern philosophers. His aim was to grasp the true character of the tradition of modern rationalim, to go beyond the prejudices created by this tradition, to gain a whole new horizon of meanings beyond modern rationalism, and in this way to retrieve the forgotten or distorted clasical political rationalism. In this framework, his study of medieval Islamic and Jewish texts gives us much to think about important issues such as the status of philosophy in non-secular societes, the relationship between faith and reason and the rationality of religion.

Strauss' philosophical thought develops around a question that he, as a Jew, first of all experienced in his own Jewish identity and which manifests itself as both the "Theological-Political Problem" and the "Theological-Political Predicament": "the question of man's right life" and "the question of the right order of society". ${ }^{2}$ Strauss rejects the view that the "theological-political problem" arose with the monotheistic understanding of god in monotheistic religions. The theological-political problem is as old as philosophy and the opposition between Athens and Jerusalem indicates that there are two alternatives to the question of what is the best political order or regime. Each of these two alternatives embodies a way of life: the life of the philosopher, represented by Socrates, and a life devoted to obedience to divine law. These alternatives, which point to the two roots, the two opposing components of Western civilization, are in the final analysis an either/or between the "wisdom of this world" or the "unquestionable wisdom of God" which is based on an "arbitrary or blind decision". For Strauss, this forces us to take sides right from the start. ${ }^{3}$

However, for Strauss, it is precisely this antagonism that presupposes a common ground as a point of reconciliation between these counterparts. This common ground is divine law (theos nomos). In this regard, both the Bible and the Greek philosophy are directly opposite to modern rationality, which, with an anthropocentric understanding of human beings, puts an emphasis on unlimited freedom and a priority of rights over duties, expresses "the radical change of moral orientation", and replaces theist theology with various alternatives such as deism, panthe-

${ }^{1}$ Because, as Strauss often emphasized, philosophy means intellectual freedom from any dogmatism, all fanaticism and "philosophy is essentially not possesion of the truth but, guest of the truth", L. Strauss, 'What is Political Philosophy?,' [in:] idem, What is Political Philosophy? and Other Studies, Chicago-London 1988, p. 11.

${ }^{2}$ For Strauss, philosophy is "genuine awareness of the problems, i.e., of the fundamental and comprehensive problems", L. Strauss, On Tyranny, V. Gourevitch, M.S. Roth (rev.ed.), Chicago-London 1988, 2000, p. 196; Natural Right and History, Chicago-London 1963, p. 32; M. Zank, 'Introduction,' [in:] Leo Strauss: the Early Writings (1921-1932), M. Zank (ed.), Albany 2002, p. 12, 17-18.

${ }^{3}$ L. Strauss, 'Thucydides: The Meaning of Political History,' [in:] The Rebirth of Classical Political Rationalism: An Introduction to the Thought of Leo Strauss, T. L. Pangle (ed.), Chicago-London 1989, p.72-73; 'Jerusalem and Athens,' [in:] idem, Studies in Platonic Political Philosophy, Chicago-London 1983 , p. 149 .

Studia Philosophica Wratislaviensia vol. XVI, fasc. 2, 2021

(C) for this edition by CNS 
ism or atheism. ${ }^{4}$ Both the Bible and Greek philosophy agree on the importance, content, and insufficiency of morality. By saying this, Strauss does not deny that there are differences between biblical morality and philosophical morality. Because, although they agree on the importance, content, and insufficiency of morality, they show a profound disagreement about as to what completes morality. Complementing morality for Greek philosophy is "understanding or contemplation". By contrast, the Bible suggests that the complement to morality is found in "humility, a sense of guilt, repentance, and faith in divine mercy". ${ }^{5}$ Besides, according to Strauss, although both biblical and philosophical morality give justice the highest place in the schema of virtues, they give different answers to the question of how justice will be accomplished. However, both Greek philosophy and the Bible define justice as "mainly obedience to the law". Neither limits the law that man must obey to just civil or positive law; it is moral and religious law at the same time.

Strauss says that both the Bible and Greek philosophy organised the order of human things according to a theology that included the concept of divine justice and punishment, and in this regard, the theology of the Bible may be as reasonable as Greek philosophy. ${ }^{6}$ According to Strauss, the main reason for the conflict between the Bible and Greek philosophy is the difference between the ideas of God. The God of the Bible is a personal, loving and punishing, graceful, incomprehensible, unpredictable, totally free, "mysterious God". He is a thinking God like Aristotle's god, but more than that, a willful God. However, Aristotle's god is a self-thinking god, pure thought. The will of the God of the Bible is beyond human comprehension. Therefore, man cannot grasp it through reason; it is known only through revelation, and man has to obey his commands. ${ }^{7}$ Therefore, according to Strauss, reason and revelation, philosophy and faith are two different lifestyles that cannot be reduced to each other and are in conflict with each other.

For Strauss, however, there is a logos of the clash of Athens and Jerusalem, of reason and faith, of philosophy and revelation. According to him, "only revelation can transform natural man into the guardian of his city," or, to use the language of the Bible, the guardian of his brother". ${ }^{8}$ Conversely, Socrates, who is aware of human ignorance in the highest issues, admits "the imperfection of human wisdom" and at the same time that people cannot live without a knowledge of the whole. Man's conception of the whole has two forms: philosophy and religion. Both accept the mystery of the whole in different ways and argue that human life can only be enriched by being open to the whole. However, philosophy opposes revelation where it says the right way of life is the pursuit of the most important things. ${ }^{9}$ Therefore, according to Strauss, "philosophy has never refuted revelation. Nor [...]

${ }^{4}$ L. Strauss, 'Progress or Return?,' [in:] The Rebirth of Classical Political Rationalism, p. 243-248.

${ }^{5}$ Ibidem, p. 246-250.

${ }^{6}$ L. Strauss, 'Jerusalem and Athens,' p. 152; K. Sorensen, 'Revelation and Reason in Leo Strauss,' The Review of Politics 65 [3] (2003), p. 389.

${ }^{7}$ L. Strauss, 'Jerusalem and Athens,' p. 162-166.

${ }^{8}$ L. Strauss, Persecution and the Art of Writing, Chicago-London 1952, p. 140.

${ }^{9}$ L. Strauss, 'Progress or Return?,' p. 258-259. 
has revelation, or rather theology, ever refuted philosophy". ${ }^{10}$ So, for Strauss, "the choice of philosophy is based on faith [...] the quest for evident knowledge rests itself on an unevident premise". ${ }^{11}$

Strauss aims to show us that philosophy owes its existence to its conflict with all divine codes, not to its reconciliation with the city and its acceptance of its conceptions of the divine. Therefore, for a true philosopher, compromise is impossible. Strauss does not see this conflict between the Bible and philosophy as something to be resolved; on the contrary, for him, "Philosophy and the Bible are the alternatives, or the antagonists in the drama of the human soul". ${ }^{12}$ According to him, every effort to dissolve these two opposing elements in a synthesis inevitably ends in the sacrifice of one of the two components to the other: either philosophy becomes the servant of theology or theology becomes the servant of philosophy. ${ }^{13}$

According to Strauss, the synthesis of philosophy and revelation took place when medieval Christian scholasticism made revelation, understood by Jewish and Islamic philosophers as Divine Law (Torah and Shari'a), the subject of knowledge. As a result, revelation begins to be seen as a matter of knowledge, not of legislation. ${ }^{14}$ In fact, like Christian philosophers, Jewish and Islamic philosophers are characterised by an effort to reconcile reason and revelation. However, according to Strauss, there is a profound difference between Christian philosophers and Islamic and Jewish philosophers. According to him, Christianity is essentially theology, not a law, and is based on sacred teaching rather than divine law. This is why Strauss prefers to use the word Law rather than revelation. Because, according to him, revelation is a very general term, and both Jewish and Islamic revelation appear in the form of the Law. ${ }^{15}$

Unlike Christianity, revelation for Islamic and Jewish philosophers precisely "was not a creed or a set of dogmas, but a social order, if an all-comprehensive order, which regulates not merely actions but thoughts or opinions as well"16. For Jewish and Islamic philosophers, the appropriate form and interpretation of "revelation as the perfect social order" is not "rational commandments" but "rational laws" (nomoi). For Strauss, the notion of "rational commandments" corresponds to the Christian notion of "natural law", which can be identified with "law of reason" and "moral law". The rejection of the notion of "rational commandments" by

${ }^{10}$ L. Strauss, 'The Mutual Influence of Theology and Philosophy,' [in:] Faith and Political Philosophy: The Correspondence between Leo Strauss and Eric Voegelin 1934-1964, P. Emberley, B.Cooper (transl., eds.), Columbia 2004, p. 232.

11 Ibidem, p. 233.

${ }^{12}$ L. Strauss, 'Progress or Return?,' p. 260.

13 L. Strauss, Natural Right and History, pp. 72-73.

${ }^{14}$ L. Batnitzky, Leo Strauss and Emmanuel Levinas: Philosophy and the Politics of Revelation, New York 2002, p. 123.

${ }^{15}$ L. Strauss, 'How to Begin to Study Medieval Philosophy,' [in:] The Rebirth of Classical Political Rationalism, p. 221; H. Fradkin, 'A Word Fitly Spoken: The Interpretation of Maimonides and the Legacy of Leo Strauss,' [in:] Leo Strauss and Judaism, D. Novak (ed.), Lanham, Maryland 1996, p. 64.

${ }^{16}$ L. Strauss, Persecution and the Art of Writing, pp. 9-10. 
falāsifa* at this point is significant, since it implicitly implies that "the principles of morality are not rational, but "probable" or "generally accepted "[principles], that is, they are not binding. In other words, by understanding revelation as law, as an "all-encompassing order", unlike Christian philosophers, Islamic and Jewish philosophers reject the identification of the principles of morality with the "law of reason" and "moral law". ${ }^{17}$

For Christians, potentially, there is a distinction between Church and State, since revelation is primarily a matter of faith. Moreover, in contrast to and unlike the Jewish and Islamic worlds, the status of philosophy in the Christian world was that "philosophy was an integral part of the officially authorized and even required training". ${ }^{18}$ In the Jewish and Islamic world, however, the status of philosophy is far more dangerous, as revelation is understood as the law that is not subject to question and demands only obedience. According to Strauss, this difference can be clearly seen in a comparison between the beginnings of Aquinas' Summa and Maimonides' Guide. The first article of Aquinas' Summa deals with 'the question as to whether theology is necessary apart from, and in addition to, the philosophic disciplines". Thus, he justifies and "defends theology before the tribunal of philosophy". The first chapter of Maimonides' Guide appears in the form of a detailed commentary on Genesis 1:27. But in fact, like his contemporary Averroes, Maimonides needs "much more urgently legal justification of philosophy, i.e., a discussion in legal terms of the question whether the Divine Law permits or forbids or commands the study of philosophy, than a philosophic justification of the Divine Law or of its study". ${ }^{19}$ This similar special and dangerous position of philosophy in both the Greek and Judeo-Islamic worlds prompts philosophers to distinguish between esoteric and exoteric writing. According to Strauss, this is the only way to preserve philosophy's inner freedom, rather than being a misfortune for philosophy. ${ }^{20}$

According to Strauss, medieval Islamic and Jewish philosophers, by understanding revelation as law, saw religion first and foremost as a political phenomenon, not a philosophical one. Therefore, for them, the philosophical discipline related to religion is not philosophy of religion, but political philosophy or political science.

\footnotetext{
* "In Islamic thought the word Falasifa (sing. Faylasuf) is derived from the Greek and specifies the ancient ones, meaning the Greek philosophers, as well as their heirs in the Islamic world, such as al-Kindi (d. 873), al-Farabi (d.950), Avicenna (d.1037) and Averroes (d.1198)" (N. Zouggar, "The Philosophers in Sunni Prophetology', transl. D. Granot, Bulletin du Centre de recherche français à Jérusalem 23 [2012], par. 13). The famous Al-Shahrastān̄̄'s list of philosophers includes the oldest "seven Sages who are "the fount of philosophy (falsafa) and the beginning of wisdom (hikma)"" (R. Arnaldez, 'Falāsifa,' [in:] Encyclopaedia of Islam, P. Bearman, T. Bianquis, C.E. Bosworth, E. van Donzel, W.P. Heinrichs [eds.], Leiden 2001, p. 764). This description alludes to the terminological nuances of the translation of the original Greek philosophōs, which in the Arabic language is synonymous with words ḩukamā, and culamā,, and in the classification and methodology of "Islamic Sciences" it is distinguished from mutakallimūn (scholars of kalām [rationalistic or scholastic theology]).

17 L. Strauss, Persecution and the Art of Writing, p. 10-11.

18 L. Strauss, 'How to Begin to Study Medieval Philosophy,' p. 221.

${ }^{19}$ L. Strauss, Persecution and the Art of Writing, p. 20.

${ }^{20}$ L. Strauss, Persecution and the Art of Writing, p. 21; 'How to Begin to Study Medieval Philosophy,' p. 223.
} 
According to Strauss, this political philosophy for Jewish and Islamic philosophers is found in Plato's Republic and Laws. Here theioi nomos, the divine law, appears once again as the common ground between philosophy and religion. Whether in the form of the God of the philosophers or the God of Abraham, the acceptance of the divine, the divine law, means the acceptance of "the idea of a concrete and binding order of life", a binding authority over human action and thought, which "is obscured by the Chtistian tradition and the modern tradition of natural right, which cast a spell over at least our philosophical thinking". ${ }^{21}$

When medieval Jewish and Islamic philosophers met Plato, they saw that revelation fulfilled three basic requirements that would enable them to reconcile reason and faith: "the law as the divine law, the prophetic lawgiver as the philosopherking, and the community of the faithful as the actualization of the ideal city". ${ }^{22}$ If revelation is law, a legislator is needed. According to Strauss, medieval Jewish and Islamic philosophers interpreted the prophet as "Platonian philosopher-king: the founder of the perfect political community", based on the divine law being given to people through a prophet. This shows us that these philosophers understood the doctrine of prophecy as part of political science. ${ }^{23}$

Strauss first turns to Maimonides to understand the relationship between philosophy and the Law. While studying Maimonides, Strauss observes that Maimonides accepted Al-Farabi as an authority alongside Aristotle, and that even Maimonides' political science derives from Farabi's teaching. ${ }^{24}$ What Strauss said about Farabi's political teaching can be seen as the repetition of what he said about the ancients, as Drury points out. ${ }^{25}$ According to Strauss, Farabi agrees with Plato on the necessity of writing in an ambiguous, suggestive and sometimes misleading style, as well as being aware of the esoteric character of Plato's writings. ${ }^{26}$ Strauss evaluates Farabi's Summary of Plato's Laws and Philosophy of Plato, its parts and the arrangement of parts from beginning to end, in the light of this understanding. According to him, in the Summary, Farabi refers to what Plato says in the Laws only by implication, and prefers to remain silent about philosophy and the philosopher. Because, according to Strauss, Summary talks about the God, gods, the otherlife, Sharia ${ }^{27 *}$ and divine laws and teaches that true happiness consists of obedience to the divine law. However, Philosophy of Plato teaches that "philosophy

${ }^{21}$ D. Jannsens, 'Questions and Caves: Philosophy, Politics and History in Leo Strauss's Early Work,' Journal of Jewish Thought and Philosophy 10 [1] (2000), p. 134.

22 Ibidem, p. 129-130.

${ }^{23}$ L. Strauss, 'How to Begin to Study Medieval Philosophy,' p. 224.

${ }^{24}$ H. Fradkin, 'A Word Fitly Spoken,' p. 65-66.

25 S. Drury, The Political Ideas of Leo Strauss, Basingstoke 1988, p. 21.

${ }^{26}$ L. Strauss, 'How Farabi Read Plato's 'Laws",' [in:] What is Political Philosophy?, p. 135-137, 145.

$27 *$ Sharia which is romanized form of Arabic term of $\operatorname{shar}_{\bar{\imath}} a h$ means Islamic law and God's immutable divine law. According to an official technical definition shar $\bar{\iota}_{\star} a h$ is "the revelation that Muhammad (ŞAAS) had received and made practicing it the message and mission of his life, i.e., the Qur'an and the Prophetic tradition" and it should be distinguished from both Fiqh (collection of juridical opinions) and Fatwa (application of shari'ah or fiqh). J. Auda, Maqūsid Al-Shariah as Philosophy of Islamic Law A Systems Approach, London 2007, p. xxiii.

Studia Philosophica Wratislaviensia vol. XVI, fasc. 2, 2021

(C) for this edition by CNS 
is the necessary and sufficient condition of happiness". From this point of view, Strauss reaches the conclusion that Philosophy of Plato with the Summary "reflects the relation between philosophy and the divine law as between two entirely different worlds". ${ }^{28}$

Like Plato, Al-Farabi thinks that true happiness is found in the theoretical life or the life of contemplation, but he accepts that the world of philosophy and revelation are completely different from each other. This means that Al-Farabi, in full agreement with the ancient understanding, understands revelation as a political phenomenon and thinks that philosophy and morality are different from each other in this context. As a direct result of this understanding, he does not see morality or moral life as good in itself; he regards it as good only instrumentally, as a means of satisfying the external conditions of philosophical life. ${ }^{29}$ Farabi, like Plato, thinks that philosophical truths are inherently dangerous to the life of the site and that the political community needs revelation or divine law to survive. In this respect, according to Strauss, Al-Farabi tries to preserve Plato's purpose under Islamic conditions. ${ }^{30}$

According to Strauss's Farabi, unlike Socrates, Plato did not only deal with moral and political issues, but essentially saw philosophy as a search for theoretical knowledge. Unlike Socrates, he believed that philosophy should be presented within a political framework. In this respect, according to Strauss's Farabi, Plato's interest in political issues serves the purpose of making the conditions of the search for theoretical knowledge possible. In doing so, he suggested a different path from Socrates. According to Strauss' Farabi, Socrates had no alternative but to accept or challenge the rules of the site and, as a result, accept the death penalty. However, Plato corrected "Socrates' intransigent way" by combining the way of Socrates with the way of Thrasymachus. ${ }^{31}$

The main theme of Farabi's political philosophy is the prophet or prophecy. For where there is divine law, a legislator is needed. In this respect, according to Strauss, Farabi uses the term "divine" as "a certain quality of human beings or of human achievements or of human pursuits, namely, their excellence". This means that "the divine laws are the work of a human legislator". ${ }^{32}$ According to Farabi, the legislator teaches other people how to live. However, for this, he must know what is right and what is wrong. This means that the legislator must be a philosopher. However, more than that, the legislative philosopher must also be a prophet. Because conveying the necessary moral information to the uneducated audience and persuading them requires having communication skills other than knowledge. Because people do not always listen to reason. As an imaginative person, the

\footnotetext{
28 L. Strauss, 'How Farabi Read Plato's "Laws",' p. 139.

29 C. Zuckert, Postmodern Platos: Nietzsche, Heidegger, Gadamer, Strauss, Derrida, Chicago 1996. p. 111-113; Ch. Colmo, 'Theory and Practice: Alfarabi's Plato Revisited,' The American Political Science Review 86 [4] (1992), p. 967.

30 L. Strauss, 'How Farabi Read Plato's 'Laws",' p. 144.

${ }^{31}$ Ibidem, p. 153; idem, Persecution and the Art of Writing, p. 16; C. Zuckert, Postmodern Platos, p. 113,115 .

${ }^{32}$ L. Strauss, 'How Farabi Read Plato's 'Laws",' p. 149.
} 
prophet has the ability to tell people how to live. From this perspective, as Farabi himself puts it, "Philosopher, Supreme Ruler, Prince, Legislator and Imam are one idea". To put it in Drury's words, "the philosopher is the godless prophet". ${ }^{33}$ According to Strauss, "Farabi's Plato eventually replaces the philosopher-king who rules openly in the virtuous city, by the secret kingship of the philosopher who, being »a perfect man « precisely because he is an »investigator «, lives privately as a member of an imperfect society which he tries to humanize within the limits of the possible". 34

According to Strauss, Farabi's substitution of "the secret kingship of the philosopher" for "the philosopher-king who clearly rules" serves to protect the independence of philosophy. Because every synthesis can only be realised at the expense of one of the parties. Seen in this way, the Farabian synthesis is not an Aquinasian synthesis; on the contrary, he hides his true teaching by giving a rational explanation of revelation as law, and thus actually belogs to philosophy. He accepts the authority of revelation and considers that philosophizing in Islamic society is possible only if it is through "authorized by the law". 35

\section{References}

Arnaldez R., 'Falāsifa,' [in:] Encyclopaedia of Islam, Second Edition, P. Bearman, T. Bianquis, C.E. Bosworth, E. van Donzel, W.P. Heinrichs (eds.), Leiden 2001, p. $764-767$.

Auda J., Maqāșid Al-Shariah as Philosophy of Islamic Law A Systems Approach, London 2007.

Batnitzky L., Leo Strauss and Emmanuel Levinas: Philosophy and the Politics of Revelation, New York 2002.

Colmo Ch., Theory and Practice: Alfarabi's Plato Revisited, The American Political Science Review 86 [4] (1992), p. 966-976.

Drury S., The Political Ideas of Leo Strauss, Basingstoke 1988.

Fradkin H., 'A Word Fitly Spoken: The Interpretation of Maimonides and the Legacy of Leo Strauss,' [in:] Leo Strauss and Judaism, D. Novak (ed.), Lanham, MD 1996, p. $55-85$.

Jannsens D., 'Questions and Caves: Philosophy, Politics and History in Leo Strauss's Early Work,' Journal of Jewish Thought and Philosophy 10 [1] (2000), p. 111-144.

Sheppard E.R., Leo Strauss and the Politics of Exile, Waltham, MA 2006.

Sorensen K., 'Revelation and Reason in Leo Strauss,' The Review of Politics 65 [3] (2003), p. 383-408.

Strauss L., 'How Farabi Read Plato's 'Laws", [in:] idem, What is Political Philosophy? and Other Studies, Chicago-London 1988, p. 134-154.

\footnotetext{
${ }^{33}$ S. Drury, The Political Ideas of Leo Strauss, p. 31.

${ }^{34}$ L. Strauss, Persecution and the Art of Writing, p. 17.

${ }^{35}$ E.R. Sheppard, Leo Strauss and the Politics of Exile, Waltham, Mass. 2006, p. 71-72.
} 
Strauss L., 'How to Begin to Study Medieval Philosophy,' [in:] The Rebirth of Classical Political Rationalism: An Introduction to the Thought of Leo Strauss, T.L. Pangle (ed.), Chicago-London 1989, p. 207-226.

Strauss L., 'Jerusalem and Athens,' [in:] idem, Studies in Platonic Political Philosophy, Chicago-London 1963, p. 147-173.

Strauss L., 'The Mutual Influence of Theology and Philosophy,' [in:] Faith and Political Philosophy: The Correspondence between Leo Strauss and Eric Voegelin 1934-1964, P. Emberley, B. Cooper (transl., eds.), Columbia 2004, p. 217-234.

Strauss L., Natural Right and History, Chicago-London 1963.

Strauss L., On Tyranny, V. Gourevitch, M.S. Roth (rev.ed.), Chicago-London 2000.

Strauss L., Persecution and the Art of Writing, Chicago-London 1952.

Strauss L., 'Progress or Return?,' [in:] The Rebirth of Classical Political Rationalism: An Introduction to the Thought of Leo Strauss, T.L. Pangle (ed.), Chicago-London 1989, p. 227-270.

Strauss L., 'Thucydides: The Meaning of Political History,' [in:] The Rebirth of Classical Political Rationalism: An Introduction to the Thought of Leo Strauss, T.L. Pangle (ed.), Chicago-London 1989, p. 72-102.

Strauss L., 'What is Political Philosophy?,' [in:] idem, What is Political Philosophy? and Other Studies, Chicago-London 1988, p. 9-55.

Zank M., 'Introduction,' [in:] Leo Strauss: the Early Writings (1921-1932), M. Zank (ed.), Albany 2002, p. 3-49.

Zouggar N., 'The Philosophers in Sunni Prophetology,' transl. D. Granot, Bulletin du Centre de recherche français à Jérusalem 23 (2012), p. 1-14.

Zuckert C., Postmodern Platos: Nietzsche, Heidegger, Gadamer, Strauss, Derrida, Chicago-London 1996. 